\title{
PENGEMBANGAN JOBSHEET DENGAN PENDEKATAN SAINTIFIK PADA MATA PELAJARAN PENGOLAHAN DAN PENYAJIAN MAKANAN DI SMK NEGERI 2 SINGARAJA
}

\author{
Ida Bagus Komang Krisnanda W., Ni Made Suriani, Cokorda Istri Raka Marsiti \\ Jurusan Teknologi Industri \\ Universitas Pendidikan Ganesha \\ Singaraja, Indonesia \\ e-mail: gustmank056@gmail.com made.suriani@undiksha.ac.id. \\ raka.marsiti@undiksha.ac.id.
}

\begin{abstract}
Abstrak
Penelitian ini bertujuan untuk mengembangkan jobsheet dengan pendekatan saintifik, dimana kegiatan ini dirancang untuk peserta didik secara aktif mengonstruk konsep, hukum atau prinsip melalui tahapan $5 \mathrm{M}$. Jenis penelitian yang digunakan adalah penelitian research and development atau penelitian pengembangan dengan model ADDIE. Subjek dalam penelitian ini yaitu siswa kelas XI A (Boga) 3. Instrumen penelitian yang digunakan berupa angket. Adapun pokok bahasan dalam pengembangan jobsheet ini yaitu : (1) kelayakan jobsheet berdasarkan uji coba ahli isi materi pembelajaran dan uji coba ahli media pembelajaran; (2) kelayakan jobsheet berdasarkan uji sasaran. Hasil penelitian menunjukkan bahwa : (1) hasil analisis ahli isi materi pembelajaran diperoleh sebesar $86 \%$ dengan kategori baik dan hasil analisis ahli media pembelajaran diperoleh $89.5 \%$ dengan kategori baik; (2) hasil analisis uji sasaran berupa respon siswa diperoleh sebesar $89.3 \%$ dengan kategori baik. Berdasarkan hasil penelitian yang diperoleh, dapat disimpulkan bahwa media yang dikembangkan layak digunakan sebagai bahan pembelajaran.
\end{abstract}

Kata kunci : jobsheet, pengembangan, saintifik

\begin{abstract}
Abstrack
This research aims to develop jobsheet with a scientific approach, in which the steps of this activity are designed for learners actively consult concepts, laws or principles through $5 \mathrm{M}$ steps. The kind of research used is research and development of ADDIE model. The subjects in this research is students from class XI A (Boga) 3. A research instrument used in questionnaire. As well as the subject of the development of this jobsheet to find out (1) the feasibility of the worksheet based on the trial of expert content of the learning materials and media expert learning; (2) Job seeker's feasibility based on target test. The result of the research shows that (1) the result of the content of learning material expert was $86 \%$ with good category and the result of the analysis of the media expert was $89.5 \%$ with good category; (2) target test analysis of student responses came to $89.3 \%$ with a good category. Based on the result of research, it can be concluded that the developed media is worthy of being used in pengolahan dan penyajian makanan subject.
\end{abstract}

Keyword : Jobsheet, Development, Saintifict 


\section{PENDAHULUAN}

Pendidikan mempunyai nilai penting bagi kemajuan bangsa Indonesia. Kemajuan suatu bangsa merupakan citacita besar yang harus diperjuangkan. Mohammad Ali (2009: 129), menyampaikan bahwa pendidikan merupakan suatu proses pada suatu bangsa dalam mempersiapkan generasi mudanya untuk menjalankan kehidupan dan untuk memenuhi tujuan hidup secara efektif dan efisien agar mereka dapat memberikan kontribusi terbaik bagi kemajuan bangsa. Hal ini memberikan gambaran bahwa pendidikan memiliki pengaruh yang signifikan terhadap kemajuan suatu bangsa.

Kemajuan suatu bangsa dan
negara dapat dilihat dari bidang
pendidikannya, sehingga apabila pendidikannya berkualitas maka sumber daya manusia yang dihasilkan berkualitas pula. Pendidikan dianggap sebagai kunci bagi suatu bangsa yang ingin maju, membangun dan berusaha memperbaiki keadaan masyarakatnya. Dunia pendidikan Indonesia di tahun 2013 diwarnai oleh isu utama, yaitu perubahan kurikulum. Penerapan Kurikulum 2006 atau yang biasa disebut dengan Kurikulum Tingkat Satuan Pendidikan (KTSP) kini digantikan dengan kurikulum 2013. Kurikulum 2013 disiapkan oleh pemerintah untuk mencetak generasi yang siap dalam menghadapi masa depan yang semakin berkembang. Peserta didik dituntut agar lebih aktif dalam proses pembelajaran dalam kurikulum 2013. Pendekatan yang digunakan dalam kurikulum 2013 adalah pendekatan yang ilmiah dalam pelaksanaannya yaitu pendekatan saintifik (Scientific Approach). Tahapan pendekatan tersebut meliputi observing (mengamati), questioning (menanya), experimenting (mengumpulkan data), associating (mengolah data), dan communicating (mengkomunikasikan) yang akan dilalui oleh peserta didik. Kurniasih dan Sani (2014) menyatakan :
Karakteristik pendekatan saintifik antara lain: 1) berpusat pada peserta didik, 2) melibatkan proses sains dalam mengontruksi konsep, hukum atau prinsip, 3) melibatkan proses-proses kognitif yang potensial dalam merangsang perkembangan intelek, khususnya keterampilan berpikir tingkat tinggi peserta didik, 4) dapat mengembangkan karakter peserta didik.

Pendekatan saintifik diterapkan dalam implementasi Kurikulum 2013 karena pendekatan ini lebih efektif dibandingkan pendekatan tradisional. Proses pembelajaran yang mengimplementasikan pendekatan saintifik meliputi 3 ranah yakni sikap (afektif), pengetahuan (kognitif) dan keterampilan (psikomotor). Dengan proses pembelajaran yang menggunakan pendekatan saintifik maka akan menghasilkan peserta didik yang produktif, kreatif, inovatif, dan afektif melalui penguatan sikap, pengetahuan, dan keterampilan yang terintegrasi. Selain itu, pendekatan saintifik juga dapat mendorong peserta didik untuk melakukan penyelidikan guna menemukan fakta-fakta dari suatu fenomena atas kejadian karena peserta didik dibiasakan untuk menemukan kebenaran ilmiah dalam berpikir logis bukan lagi beropini dalam melihat fenomena.

Lembaga pendidikan formal yang berada pada jenjang pendidikan menengah adalah SMK (Sekolah Menengah Kejuruan) yang menuntut peserta didiknya memiliki keahlian dan keterampilan. Dengan demikian SMK dapat dikatakan sebagai pencetak tenaga kerja yang siap kerja dan berkompeten tanpa harus melanjutkan pendidikan ke jenjang yang lebih tinggi. Salah satu SMK yang berada di Singaraja yaitu SMK Negeri 2 Singaraja memiliki program 
keahlian Kuliner yang berfokus dalam bidang makanan dan minuman serta pelayanan. Di SMK peserta didik tidak hanya mendapatkan mata pelajaran normatif seperti Bahasa Indonesia, Bahasa Inggris, Agama dan lain-lain. Peserta didik juga mendapatkan pelajaran produktif sesuai dengan bidang keahlian yang ingin digeluti seperti Tata Hidang, Pengolahan Makanan Indonesia, Pengolahan dan Penyajian Makanan Kontinental dan lain sebagainya.

SMK Negeri 2 Singaraja telah menerapkan Kurikulum 2013 pada jenjang kelas X, XI dan kelas XII. Perubahan kurikulum dari KTSP (Kurikulum Tingkat Satuan Pendidikan) ke Kurikulum 2013 tersebut tentunya mempengaruhi berbagai aspek. Salah satu permasalahan yang timbul dengan adanya kurikulum 2013 di SMK adalah munculnya beberapa mata pelajaran produktif baru pada kompetensi keahlian. Kurikulum 2013 sebenarnya telah dirancang sedemikian rupa dengan terbitnya Buku Kurikulum 2013. Akan tetapi munculnya buku kurikulum 2013 di SMK dirasa belum praktis dalam kegiatan praktik peserta didik sesuai dengan kondisi sarana dan prasarana yang ada di sekolah. Sehingga guru lebih banyak menyampaikan teori dari pada kegiatan praktik. Kondisi tersebut berkebalikan dengan tujuan dari mata pelajaran pengolahan dan penyajian makanan yang mengharapkan dapat mengembangkan keterampilan peserta didik dalam mengolah dan menyajikan sebuah makanan sesuai dengan kompetensi inti (KI) dan komptensi dasar (KD).

Penulis memilih mata pelajaran pengolahan dna penyajian makanan karena kompetensi dasar pada mata pelajaran ini sesuai dengan kurikulum 2013 meliliki kompetensi dasar yang sangat padat yaitu terdiri dari 26 kompetensi dasar yang akan dipelajari selama 2 tahun, yaitu pada kelas XI dan
XII. Sehingga pemahaman yang lebih mendalam dan lebih detail sangat diperlukan agar peserta didik mampu menerima materi pembelajaran berikutnya dengan lebih cepat. Disamping itu juga mata pelajaran pengolahan dan penyajian makanan merupakan mata pelajaran yang mencakup tentang masakan-masakan western atau makanan dari Negara Eropa. Sehingga banyak bahan-bahan makanan yang tidak umum ditemui di Indonesia. Maka dari itu peserta didik perlu terus menerus mempelajari dan memahami bahan-bahan makanan tersebut, yang dapat dibantu oleh jobsheet yang dirancang oleh penulis.

Munculnya mata pelajaran baru tentunya menimbulkan berbagai persoalan yang berhubungan dengan kesiapan guru dalam mengajar. Berdasarkan informasi yang diperoleh dari hasil observasi terhadap guru di program keahlian Kuliner, guru merasa penggunaan media pembelajaran yang sebelumnya belum relevan, sehingga kegiatan praktik yang dilakukan hanya didasarkan pada instruksi lisan dari guru untuk semua peserta didik. Kondisi ini mengakibatkan kurangnya informasi yang didapatkan peserta didik dalam pelaksanaan praktikum.

Pengolahan dan penyajian makanan merupakan salah satu mata pelajaran produktif bagi peserta didik kelas XI dengan program keahlian Kuliner, di SMK Negeri 2 Singaraja. Mata pelajaran tersebut diberikan kepada peserta didik selama 2 semester yaitu semester ganjil dan juga genap. Dalam penelitian ini penulis membuat jobsheet untuk semester genap dengan 6 Kompetensi Dasar diantaranya : (1) Menganalisis dan menunjukkan pembuatan telur, (2) Menganalisis dan menunjukkan pembuatan hidangan dari unggas, (3) Menganalisis dan menunjukkan pembuatan hidangan dari 
daging, (4) Menganalisis dan menunjukkan hidangan dari ikan dan seafood, (5) Menganalisis dan menunjukkan pembuatan hidangan dari sayur, (6) Menganalisis dan menunjukkan pembuatan hidangan penutup. Sebelum praktik dilakukan, peserta didik diminta untuk mengerjakan perencanaan praktek berdasarkan resep yang diberikan oleh guru sebagai media pembelajaran yang dapat mendukung dalam pelaksanaan praktik.

Media pembelajaran secara umum adalah alat bantu proses belajar mengajar. Segala sesuatu yang dapat dipergunakan untuk merangsang pikiran, perasaan, perhatian dan kemampuan atau ketrampilan pebelajar sehingga dapat mendorong terjadinya proses belajar. Media pembelajaran berfungsi untuk memperjelas makna pesan yang disampaikan, sehingga dapat mencapai tujuan pembelajaran dengan lebih baik dan sempurna. Media pembelajaran merupakan sarana untuk meningkatkan kegiatan proses belajar mengajar. (Munadi, 2008:7)

Media pembelajaran yang digunakan seorang guru pada proses belajar mengajar yang dilakukannya harus dapat mendukung ketercapaian kompetensi yang telah ditetapkan. Faktor yang harus diperhatikan dalam pemilihan media diantaranya adalah kesesuaian materi, keefektifan dan kesesuian dengan sistem pendidikan yang berlaku. Penggunaan media pada pembelajaran teori tentu akan berbeda dengan media yang digunakan pada pembelajaran praktik. Oleh karena itu seorang guru harus dapat memilih maupun membuat media pembelajaran yang tepat bagi peserta didik.

Pada pembelajaran teoritis dengan metode ceramah seringkali peserta didik merasa tidak tertarik untuk belajar dan sulit untuk memahami resep yang merupakan pengetahuan dasar dalam pembelajaran praktik yang dilakukan. Akibatnya banyak peserta didik yang tidak dapat menjawab pertanyaan pre-test (sesaat sebelum praktik) maupun bingung saat praktik karena tidak hafal atau tidak paham dengan langkah kerja yang harus dilakukan. Tidak jarang peserta didik membuka dan membaca resep kembali ketika praktik dilakukan sehingga menghambat kerja peserta didik. Sedangkan jika menggunakan jobsheet yang sudah dikembangkan peserta didik akan dituntut untuk memahami segala resep dan menuntaskan beberapa latihanlatihan yang akan menunjang daya ingat peserta didik mengenai resep yang akan dipraktikan. Oleh karenanya membuka resep saat praktik berlangsung dapat diminimalisir dan proses praktikum dapat berjalan lebih cepat.

Kerja peserta didik terhambat karena peserta didik kurang memahami langkah kerja yang harus mereka lakukan sehingga peserta didik harus pulang lebih dari jam sekolah yang telah dijadwalkan. Berdasarkan masalah tersebut maka diperlukan sebuah media pembelajaran yang cukup menarik bagi peserta didik sehingga peserta didik tertarik untuk mempelajari dan memahami langkah kerja yang harus dilakukan agar waktu dapat dimanfaatkan sebaik-baiknya dalam satu kali tatap muka pembelajaran praktik pengolahan dan penyajian makanan.

Media yang digunakan guru dalam pembelajaran praktik pengolahan dan penyajian makanan berupa lembaran resep yang dibagikan kepada masingmasing kelompok peserta didik. Resep ini sebenarnya sudah menunjukkan langkah kerja yang harus dilakukan peserta didik, namun karena penyajian resep yang kurang baik sehingga sulit dipahami oleh peserta didik. Hingga saat ini belum ada pengembangan media pembelajaran yang relevan dalam pembelajaran pengolahan 
dan penyajian makanan padahal media pembelajaran sangat diperlukan sebagai penuntun kerja peserta didik pada saat praktikum.

Jobsheet harus dibuat dengan jelas dan menarik agar peserta didik paham dan tertarik untuk mengikuti pelajaran. Hasil observasi kelas pada tanggal 24 April 2018 menunjukkan, dalam pelaksanaan pembelajaran praktik di SMK Negeri 2 Singaraja khususnya kelas XI Kuliner belum menggunakan jobsheet yang disediakan sebagai media yang dapat digunakan peserta didik untuk belajar ketika praktik berlangsung.

Berdasarkan uraian di atas, penulisan memiliki tujuan untuk menyusun dan menghasilkan suatu media pembelajaran berupa jobsheet untuk memperlancar kegiatan pembelajaran praktik dan menguji kelayakannya sebagai media pembelajaran.

\section{MODEL PENELITIAN}

Penelitian ini merupakan penelitian research and development (R\&D) atau yang disebut juga dengan penelitian pengembangan yaitu metode penelitian yang digunakan untuk menghasilkan suatu produk tertentu dan menguji keefektifan produk tertentu. Tujuan dari penelitian pengembangan ini adalah untuk mengembangkan jobsheet mata pelajaran pengolahan dan penyajian makanan, dan menghasilkan jobsheet sebagai media pembelajaran praktik pengolahan dan penyajian makanan siswa kelas XI keahlian Kuliner di SMK Negeri 2 Singaraja. Model pengembangan jobsheet yang digunakan adalah model ADDIE yang dikembangkan oleh Dick and Carry (dalam Tegeh dkk, 2014) dan merupakan singkatan dari Analyze, Design, Development or Production, Implementation or Delivery, and Evaluations. Pemilihan model ini didasari atas pertimbangan bahwa model ini dikembangkan secara sistematis dan memiliki alur yang prosedural.

\begin{tabular}{lll}
\multicolumn{1}{c}{ Model ADDIE merupakan } \\
singkatan dari Analyze, Design, \\
Development & or & Production,
\end{tabular}
Implementation or Delivery, and Evaluations memiliki 5 tahapan yang dilakukan secara prosedural. Tahapan model ADDIE dapat dilihat pada Gambar 1.1

Gambar 3.1 Tahapan Model ADDIE

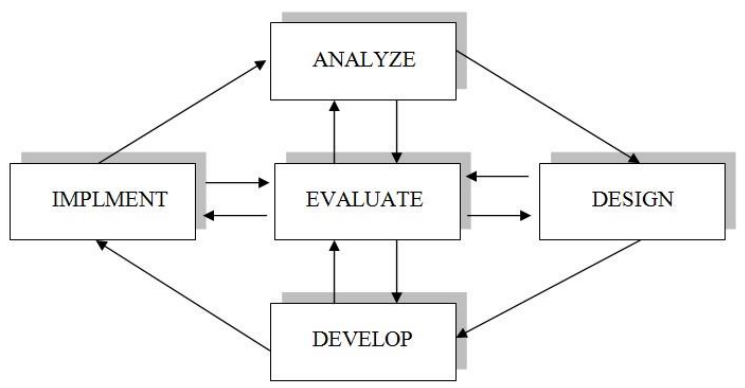

(Sumber : Tegeh dkk, 2014)

Uji coba produk pengembangan dalam penelitian ini terdiri dari 3 tahap. Yang pertama yaitu uji ahli isi materi pembelajaran yang akan divalidasi oleh 2 validator diantaranya Ricky Surya Putra, S. Pd selaku guru pengajar mata pelajaran pengolahan dan penyajian makanan kelas XI Kuliner di SMK Negeri 2 Singaraja dan salah satu dosen Tata Boga di Program Studi Pendidikan Kesejahteraan (PKK) Universitas Pendidikan Ganesha, Dr. Dra. Risa P. Ariani, M.Si. selaku dosen Tata Boga.

Tahap kedua yaitu uji ahli media pembelajaran yang akan divalidasi oleh 2 validator diantaranya Dr. Ketut Agustini, S. Si., M. Si. selaku dosen Pendidikan Teknik Informatika dan Dewa Gede Agus Putra Prabawa, S. Pd., M. Pd. selaku dosen Teknologi Pendidikan Universitas Pendidikan Ganesha. Setelah jobsheet direvisi dan dinyatakan layak berdasarkan uji ahli isi dan media pembelajaran barulah jobsheet dapat diterapkan di kegiatan belajar mengajar di kelas untuk dilakukan uji sasaran. Tahap ketiga yaitu uji sasaran dilakukan setelah siswa melaksanakan pembelajaran menggunakan jobsheet pengolahan dan penyajian makanan berbasis saintifik melalui respon siswa yang nantinya 
berguna untuk menyempurnakan produk kembali sehingga diproleh hasil akhir yang sesuai dengan tujuan penelitian.

Subjek uji coba dari produk hasil penelitian Pengembangan Jobsheet Berbasis Saintifik untuk Mata Pelajaran pengolahan dan penyajian makanan Siswa Kelas XI Kuliner di SMK Negeri 2 Singaraja antara lain : Ahli Isi Materi Pembelajaran. Tahap Penilaian dilakukan oleh ahli isi materi pembelajaran dalam penelitian ini adalah Ricky Surya Saputra, S. Pd salah satu guru yang mengajar mata pelajaran pengolahan dan penyajian makanan Siswa Kelas XI Kuliner SMK Negeri 2 Singaraja dan Dr. Dra. Risa P. Ariani, M. Si. selaku salah satu dosen Tata Boga di Program Studi Pendidikan Kesejahteraan Keluarga (PKK) Universitas Pendidikan Ganesha. Validator isi diminta ketersediaannya untuk menilai hasil produk dalam penelitian tersebut dengan alasan sudah berpengalaman dalam mengampu mata kuliah dan mata pelajaran tersebut. Penentuan subjek penelitian ahli isi materi pembelajaran diperoleh menggunakan metode Purposive Sampling yaitu penentuan subjek berdasarkan tujuan penelitian.

Selanjutnya adalah ahli media pembelajaran. Tahap Penilaian dilakukan oleh ahli media pembelajaran dalam penelitian ini adalah Dr. Ketut Agustini, S. Si., M. Si. selaku dosen Pendidikan Teknik Informatika dan Dewa Gede Agus Putra Prabawa, S. Pd., M. Pd. selaku dosen Teknologi Pendidikan Universitas Pendidikan Ganesha. Validator ahli media pembelajaran diminta ketersediaannya untuk menilai hasil produk dalam penelitian tersebut dengan alasan sudah berpengalaman dalam bidangnya.

Sasaran dalam penelitian ini yaitu siswa kelas XI Kuliner yang mendapatkan pelajaran pengolahan dan penyajian makanan sebagai subjek uji coba lapangan dari penelitian yang dilakukan di SMK Negeri 2 Singaraja. Subjek tersebut diperoleh dengan metode Simple Random. Uji sasaran dilakukan untuk mengetahui respon siswa setelah menggunakan jobsheet dalam proses pembelajaran.
Jenis data dalam penelitian ini merupakan data kuantitatif yang berarti data yang dikumpulkan disusun secara sistematis dalam bentuk angka-angka atau presentase mengenai suatu objek yang diteliti. Data tersebut yaitu validasi dalam bentuk persentase yang diperoleh dari angket yang dijadikan sebagai instrumen penilaian dalam menilai kelayakan jobsheet pengolahan dan penyajian makanan Kelas XI Kuliner di SMK Negeri 2 Singaraja berdasarkan uji ahli isi materi pembelajaran, uji ahli media pembelajaran dan uji sasaran.

Validasi isi materi pembelajaran akan menilai dari aspek kelayakan isi, kebahasaan, sajian, dan kemanfaatan. Validasi media pembelajaran akan menilai dari aspek konsistensi, format, organisasi, daya tarik, ukuran huruf, dan ruang (spasi) kosong. Sedangkan respon siswa berdasarkan aspek feedback atau balikan, penguasaan tuntas atau mastery, tujuan, motivasi, fleksibilitas dan kerjasama.

Analisis data yang dilakukan dalam proses pengembangan jobsheet ini yaitu analisis validasi/kelayakan jobsheet melalui ahli isi materi pembelajaran dan ahli media pembelajaran serta uji sasaran penggunaan jobsheet. Validasi isi materi pembelajaran diperoleh melalui ahli isi materi pembelajaran. Tujuannya yaitu untuk mengetahui apakah materi yang terkandung di dalam jobsheet sudah sesuai dengan konsep pengetahuan/indikator yang ingin dicapai. Pembelajaran, kurikulum, isi materi, pemakaian kata-kata serta bahasa dan penanganan masalah merupakan bagian dari konsep pengetahuan/indikator. Detail kegiatan pembelajaran yang dilakukan diketahui oleh ahli isi materi pembelajaran sehingga angket digunakan untuk memvalidasi jobsheet.

Penilaian hasil uji ahli isi materi pembelajaran, ahli media pembelajaran dan uji sasaran dihitung dengan rumus berikut:

$$
\text { Presentase }=\frac{\sum \text { Skor }}{S M I} \times 100 \%
$$

Keterangan : 
$\Sigma$ Skor = jumlah skor yang diperoleh

$\mathrm{SMI}=$ skor maksimal ideal

$$
\text { Rerata Presentase }=\mathrm{F} / \mathrm{N}
$$

Keterangan :

$\mathrm{F}=$ jumlah presentase keseluruhan

$\mathrm{N}$ = banyak subjek

\section{HASIL DAN PEMBAHASAN}

Pada tanggal 2-12 Mei 2019 dilakukan validasi jobsheet berdasarkan uji coba ahli isi materi pembelajaran yang melibatkan 2 orang yaitu Ricky Surya Saputra, S. Pd. yaitu salah satu guru yang mengajar mata pelajaran pengolahan dan penyajian makanan di kelas XI SMK Negeri 2 Singaraja sebagai ahli 1 dan Dr. Dra. Risa P. Ariani, M. Si. selaku salah satu dosen Tata Boga di Program Studi Pendidikan Kesejahteraan Keluarga (PKK) Universitas Pendidikan Ganesha sebagai ahli 2. Uji ahli isi materi pembelajaran dilakukan guna mendapatkan validasi jobsheet dari segi penyajian materi.

Penyerahan jobsheet disertai dengan instrumen penilaian berupa angket yang terdiri dari 4 aspek penilaian dan 25 butir indikator yang dikembangkan oleh peneliti dan diisi oleh masing-masing ahli.

Berdasarkan rumus persentase, hasil yang diperoleh untuk uji ahli isi 1 sebesar $80 \%$ dan uji ahli isi 2 yaitu sebesar $92 \%$ dan berdasarkan rumus rerata presentase yang diperoleh yaitu sebesar $86 \%$ sehingga bila dikonversikan ke dalam tabel konversi maka jobsheet yang dikembangkan berdasarkan penilaian uji ahli isi materi pembelajaran berada dalam kualifikasi sangat baik dan tidak perlu direvisi.

Berdasarkan tanggapan/penilaian dari 2 orang uji ahli isi materi pembelajaran melalui angket diproleh pencapaian dengan kualifikasi baik dan tidak perlu direvisi, namun revisi perlu dilakukan mencermati dari masukan dan komentar yang diberikan oleh ahli isi.

Berdasarkan rumus presentase, hasil yang diperoleh untuk uji ahli isi 1 sebesar $90 \%$ dan uji ahli isi 2 yaitu sebesar $89 \%$ dan berdasarkan rumus rerata presentase yang diperoleh yaitu sebesar $89.5 \%$ sehingga bila dikonversikan ke dalam tabel konversi maka jobsheet yang dikembangkan berdasarkan penilaian uji ahli media pembelajaran berada dalam kualifikasi sangat baik.

Berdasarkan rumus presentase, hasil yang diperoleh untuk respon siswa yaitu sebesar $89.3 \%$ sehingga bila dikonversikan ke dalam tabel konversi maka jobsheet yang dikembangkan berdasarkan penilaian uji sasaran berupa angket respon peserta didik berada dalam kualifikasi baik dan tidak perlu direvisi. Hal ini mengidentifikasikan bahwa pengembangan jobsheet pengolahan dan penyajian makanan berbasis saintifik menunjukkan keberhasilan yang terbukti dari tingginya respon peserta didik terutama terbantunya peserta didik dalam proses pembelajaran serta praktikum.

\section{PEMBAHASAN}

Tahap pertama yang dilakukan untuk mengembangkan jobsheet adalah tahap analisis (analyze). Pada tahap ini peneliti menganalisis kebutuhan pendidik dan peserta didik di kelas. Apa yang dibutuhkan Fdalam pembelajaran yaitu jobsheet pengolahan dan penyajian makanan yang sudah disusun secara sistematis dan mencakup materi yang akan dipelajari. Peneliti menganalisi Kompetensi Inti (KI) kelas, Kompetensi Dasar (KD) mata pelajaran pengolahan dan penyajian makanan, Indikator Pencapaian Kompetensi, Silabus, Rencana Pelaksanaan Pembelajaran (RPP), dan Buku Pengayaan yang diterapkan di sekolah khususnya pada mata pelajaran pengolahan dan penyajian makanan.

Berdasarkan analisis kurikulum tersebut didapatkan KD yang akan diberikan pada semester 2 ada 6 antara lain : (1) Menganalisis dan menunjukkan hidangan dari telur; (2) Menganalisis dan menunjukkan pembuatan hidangan dari daging; (3) Menganalisis dan menunjukkan pembuatan hidangan unggas; (4) Menganalisis dan menunjukkan pembuatan hidangan dari ikan dan seafood, (5) Menganalisis dan menunjukkan pembuatan hidangan dari 
sayur, (6) Menganalisis dan menunjukkan hidangan penutup.

Setelah menganalisis kurikulum yang diterapkan, peneliti menganalisis karakter peserta didik di SMK Negeri 2 Singaraja yaitu peserta didik kesulitan untuk menyaring informasi di internet karena luas dan banyaknya informasi yang tersedia sehingga peserta didik membutuhkan suatu bahan ajar yang merangkum keseluruhan materi yang hendak mereka praktikkan sesuai dengan kurikulum sekolah. Sehingga dari analisis tersebutlah peneliti dapat merancang jobsheet yang cocok sebagai solusinya.

Selanjutnya yaitu tahap kedua atau tahap desain, Setelah melakukan analisis kebutuhan maka dilanjutkan dengan tahap desain (design) pada tahap kedua yaitu dengan memetakan kerangka bahan ajar yang akan disusun, kompetensi dasar, materi pokok, serta garis-garis besar dalam materi yang terkait dengan KD. Jobsheet yang dikembangkan terdiri dari 6 kegiatan pembelajaran yang setiap kegiatannya berbasis saintifik yang mengacu pada Direktorat Jendral SMK tahun 2013 sehingga dalam tahap kedua ini diperoleh kerangka buram jobsheet.

Setelah tahap desain, barulah tahap pengembangan (development) dilakukan. Pada tahap ini materi dalam kegiatan pembelajaran yang sebelumnya berupa garis-garis besar dikembangkan secara detail sehingga sesuai dengan KD dan mencapai tujuan pembelajaran. Kemudian kerangka jobsheet yang meliputi 5 bagian yaitu sampul masing-masing jobsheet, materi pembelajaran, resep, tugas serta pelengkap yang menyempurnakan komponen jobsheet seperti daftar isi, panduan penggunaan jobsheet, kompetensi inti dan kompetensi dasar, daftar pustaka, serta lampiran disatukan mejadi satu kesatuan sehingga diperoleh jobsheet cetak berbasis saintifik. Sebelum diuji kelayakannya berdasarkan uji ahli isi materi pembelajaran dan media pembelajaran, jobsheet tersebut direvisi oleh pembimbing guna meminimalisir kesalahan sebelum divalidasi.

Setiap kegiatan pembelajaran disesuaikan dengan pendekatan kurikulum 2013 yaitu berbasis saintifik yang meliputi 5 kegiatan diantaranya mengamati, menanya, mengumpulkan data, mengasosiasi dan mengkomunikasikan. Kelima kegiatan pembelajaran berbasis saintifik tesebut disesuaikan dengan materi yang hendak dipelajari pada setiap Kompetensi Dasar (KD). Materi dalam KD dikembangkan dari mata pelajaran sebelumnya, materi dari internet serta pengalaman peneliti yang sudah dirangkum sesuai dengan EYD dan bahasa yang mudah dipahami oleh peserta didik.

Agar jobsheet dinyatakan valid maka dilakukan uji ahli isi materi pembelajaran yang dilakukan oleh 2 orang ahli isi pembelajaran dan ahli media pembelajaran. Selain para ahli, uji sasaran juga perlu dilakukan untuk mengetahui respon peserta didik karena untuk mengevaluasi kembali jobsheet karena setiap tahap yang dilakukan peneliti tidak terbatas dari adanya kesalahan.Validasi para ahli yang dilaksanakan diperoleh persentase $86 \%$ berdasarkan uji ahli isi pembelajaran sedangkan $89.5 \%$ berdasarkan validasi ahli media pembelajaran sehingga bila dikonversikan ke dalam tabel konversi maka jobsheet yang dikembangkan berada dalam kualifikasi baik dan tidak perlu direvisi.

Setelah melalui proses pengembangan dan jobsheet sudah dinyatakan valid maka jobsheet sudah siap diimplementasikan di dalam proses pembelajaran. Dalam tahap ini disebut dengan tahap implementasi. Dalam tahap ini jobsheet yang sudah divalidasi oleh beberapa ahli dan direvisi sesuai penilaian dan masukan para ahli selanjutnya diterapkan dalam satu kegiatan praktikum guna mengetahui kemampuan peserta didik mengenai jobsheet yang dikembangkan. Dalam penerapannya, jobsheet yang dikembangkan berbasis saintifik yang dapat dilihat dari langkahlangkah pembelajaran yang dilalui peserta didik diantaranya mengamati yaitu peserta didik mengamati materi pembelajaran dan menyebutkan nama bahan makanan sesuai dengan resep yang disediakan secara berkelompok sebagai langkah 
pertama dalam pembelajaran menggunakan jobsheet berbasis saintifik.

Langkah berikutnya yang dilakukan dalam kegiatan pembelajaran atau pada saat implementation yaitu menanya. Dalam tahap menanya peserta didik diarahkan untuk menanyakan bahanbahan dari suatu hidangan yang belum diketahui dalam resep. Tahapan ini berguna untuk mengukur sejauh mana peserta didik tersebut dapat mengamati materi pembelajaran dan memahami bahan-bahan yang sesuai dengan resep yang diberikan. Langkah selanjutnya yaitu mengumpulkan data. Pada tahap ini peserta didik diarahkan untuk merancang persiapan praktek untuk menyajikan sebuah hidangan sesuai dengan kompetensi dasar pengolahan dan penyajian makanan sehingga diharapkan peserta didik memahami materi yang diajarkan. Kemudian tahap berikutnya yaitu mengasosiasi. Dalam tahap ini peserta didik diarahkan untuk dapat menyajikan sebuah hidangan dalam pembelajaran praktikum. Hasil hidangan yang sudah diselesaikan kemudian dikumpulkan kepada pendidik.

Tahapan terakhir pendekatan saintifik yaitu mengkomunikasikan. Dalam tahap ini peserta didik diarahkan untuk memprsentasikan hasil dari hidangan yang dikerjakan kelompoknya sedangkan kelompok lain menanggapi dengan memberikan pertanyaan terkait dengan hal-hal yang tidak didapatkan. Setelah semuanya sudah selesai dibahas barulah pendidik dan peserta didik menyimpulkan hasil dari pembelajaran hari ini. Setelah satu kegiatan pembelajaran selesai maka di akhir pembelajaran peneliti membagikan instrumen berupa angket kepada seluruh peserta didik di kelas untuk mengetahui respon peserta didik setalah melakukan pembelajaran menggunakan jobsheet. Hasil yang diperoleh menggunakan rumus Tegeh yaitu $89.3 \%$. Dengan demikian dapat dinyatakan bahwa jobsheet pengolahan dan penyajian makanan layak digunakan dalam pembelajaran sehingga peneliti berhasil mengembangkan jobsheet pengolahan dan penyajian makanan.
Setiap tahap yang dilakukan oleh peneliti tidak luput dari adanya kesalahankesalahan baik yang disengaja maupun yang tidak disengaja. Tahap akhir dari pengembangan ini yaitu Evaluasi (evaluation) berguna untuk menyempurnakan jobsheet yang dikembangkan kembali sehingga diperoleh produk yang diharapkan. Biasanya hal yang tidak luput dari kesalahan yaitu masih terdapat penulisan kata yang salah atau penggunaan tanda baca yang kurang sesuai sehingga hal tersebut harus dapat diperbaiki lagi oleh peneliti.

\section{SIMPULAN DAN SARAN SIMPULAN}

Berdasarkan hasil penelitian dan pembahasan pada penelitian maka kesimpulannya antara lain , Validitas pengembangan media pembelajaran Jobsheet dengan pendekatan saintifik untuk mata pelajaran pengolahan dan penyajian makanan peserta didik kelas XI Kuliner di SMK Negeri 2 Singaraja berdasarkan uji coba ahli isi materi pembelajaran yaitu sebesar $86 \%$ berdasarkan rumus Tegeh dan bila dikonversikan berada pada kategori baik dan tidak perlu direvisi. Dan berdasarkan uji coba ahli media pembelajaran yaitu sebesar $89.5 \%$ berdasarkan rumus Tegeh dan bila dikonversikan berada pada kategori baik dan tidak perlu direvisi

Validitas pengembangan media pembelajaran Jobsheet dengan pendekatan saintifik untuk mata pelajaran pengolahan dan penyajian makanan peserta didik kelas XI Kuliner di SMK Negeri 2 Singaraja berdasarkan uji sasaran berupa angket respon peserta didik yaitu sebesar $89.3 \%$ berdasarkan rumus Tegeh dan bila dikonversikan berada pada kategori baik dan tidak perlu direvisi.

\section{Saran}

Berdasarkan beberapa simpulan yang telah dikemukakan, maka penulis dapat ajukan saran-saran sebagai berikut : (1) Kepada guru pengajar SMK Negeri 2 Singaraja yang terkait dengan mata pelajaran pengolahan dan penyajian 
Jurnal Bosaparis: Pendidikan Kesejahteraan Keluarga

Volume 10, Nomor 3, November 2019

makanan dapat melaksanakan pembelajaran secara berkelanjutan dengan berbantuan jobsheet yang dibuat oleh peneliti dengan mempertimbangakan situasi dan kondisi (2) Bagi peserta didik yang akan melanjutkan penelitian pengembangan jobsheet diharapkan dapat mengembangkan jobsheet lanjutan yang memuat semua kompetensi dasar yang tercantum pada kurikulum 2013 dan lebih memperhatikan faktor lain yang memengaruhi keberhasilan peneliti dalam mencari respon peserta didik seperti membagikan jobsheet secara individu agar hasil yang diproleh lebih maksimal.

(3) Bagi peneliti lanjutan sebaiknya ditambahkan uji ahli seperti ahli desain pembelajaran, uji kelompok kecil dan uji kelompok besar sehingga jobsheet yang dikembangkan lebih sempurna lagi. Pada uji sasaran sebaiknya dilakukan uji terbatas sehingga jobsheet yang sudah divalidasi dapat dengan lengkap diimplementasikan serta sebelum menyerahkan instrumen kepada para ahli sebaiknya instrumen diuji terlebih dahulu validitasnya.

\section{DAFTAR RUJUKAN}

Ali, Mohammad. 2009. Pendidikan Untuk Pembangunan Nasional. Bandung: PT. Imperial Bhakti Utama.

Andi Prastowo. 2012. Panduan Kreatif Membuat Bahan Ajar Inovatif. Yogjakarta: Diva Press

Aryadi Widya, dkk. 2011. Peningkatan Hasil Belajar Melalui Penerapan Media Pembelajaran Jobsheet Pada Panel Peraga Sistem Kelistrikan Otomotif. Universitas Negeri Semarang. Vol. 11. No. 2. Hal. 6871. Tersedia dalam Http://journal.unnes.ac.id

Agung, A.A. Gede. 2014. Metodologi Penelitian Pendidikan. Singaraja: Undiksha.

BSNP. 2008. Pedoman Penyusunan Kurikulum Tingkat Satuan Pendidikan Jenjang Sekolah Dasar. Jakarta: BSNP
Depdiknas, $2008 . \quad$ Panduan Pengembangan Bahan Ajar. Departemen Pendidikan Nasional Direktorat Jendral Manajemen Pendidikan Dasar dan Menengah Direktorat Pembinaan Sekolah Menegah Atas.

Direktorat Pembinaan Sekolah Menengah Kejuruan, 2017. Kompetensi Keahlian Tata Boga. Lampiran Keputusan Direktur Jendral Pendidikan Dasar dan Menengah. NOMOR : 330/D.D5/KEP/KR/2017.

Fatmawati, dkk. 2014. Makalah Pembuatan Jobsheet. Makassar: Pendidikan Kesejahteraan Keluarga, Fakultas Teknik, Universitas Negeri Makassar

https://psmk.kemdikbud.go.id/konten/2505 /kompetensi-inti-dan-kompetensidasar-ki-kd-smkmak diakses pada tanggal 22 Agustus 2018 pukul 09.45 WITA

Isjoni. 2008. Memajukan Bangsa dengan Pendidikan. Yogayakarta: Pustaka Pelajar

Jumargo, dkk. 2011. Peningkatan Hasil Belajar Kompetensi Melakukan Pekerjaan dengan Mesin Bubut dengan Menggunakan Jobsheet hasil Pengembangan. Universitas Negeri Semarang. Vol. 11. No. 2. Hal.57-62. Tersedia dalam Http://journal.unnes.ac.id

Kurniasih, Imas dan Berlin Sani. 2014. Sukses Mengimplementasikan Kurikulum 2013.Yogyakarta: Kata Pena

Koyan, I Wayan. 2011. Asesmen dalam Pendidikan. Singaraja: UNDIKSHA Press.

Musfiqon, HM dan Nurdyansyah. 2015. Pendekatan Pembelajaran Saintifik. Sidoarjo. Nizamia Learning Center

Nurtyas, Densa. 2017. "Pengembangan Multimedia Pembelajaran Interaktif Berorientasi Pembelajaran 
Kontekstual Dalam Pembelajaran IPA Kelas Vi Semester Genap Di SDN 5 Banyuning Singaraja Tahun Pelajaran 2017/2018" (Skripsi Jurusan Teknologi Pendidikan, FIP, Undiksha)

Nurhasanah, Anissa, dkk. 2016. "Analisis Penggunaan Jobsheet Pada Praktikum Dasar Boga Di SMKN 9 Bandung". Universitas Pendidikan Indonesia. Vol. 6. No. 2. Tersedia dalam Http://ejournal.upi.edu

Parmiti, Desak. 2014. Pengembangan Bahan Ajar: Jurusan Teknologi Pendidikan, Fakultas IImu Pendidikan Universitas Pendidikan Ganesha.

Pratiwi, Ni Kadek Emma. 2017. "Pengembangan Jobsheet Berbasis Media Fragmen Dalam Pembelajaran Praktek Tehnik Tailoring" (Skripsi Jurusan Pendidikan Kesejahteraan Keluarga, FTK, Undiksha)

Sadiman, A.S., Rahardjo R.Haryono, A. dan Rahardjito. 2006. Media Pendidikan: Pengertian, Pengembangan dan Pemanfaatan. Jakarta: PT Raja Grafindo Persada

Sukarjo. 2006. Kumpulan Materi Evaluasi Pembelajaran. Yogyakarta: Universitas Negeri Yogyakarta

Sugiyono. 2013. Metode Penelitian Pendidikan Kuantitatif, Kualitatif, dan R \& D. Bandung : Alfabeta.

Triasih, Dias. 2016. "Pengembangan Media Pembelajaran Job Sheet Variasi Produk Cake Kelas Xi Patiseri Di Smk Negeri 4 Yogyakarta". Universitas Negeri Yogyakarta. Vol. 5. Tersedia dalam Http://journal.uny.ac.ic

Tooling Univercity. 2013. CNC Control: Mazak Training. Diakses dari: http://www.toolingu.com/definition330280-45611-job-sheet.html. Pada tanggal 2 Agustus 2018 Pukul 12.15 WITA

Trianto. 2012. Mendesain Model Pembelajaran Inovatif Progresif. Jakarta: Kencana Prenada Media Group

Undang-Undang Republik Indonesia No. 20 tahun 2003. 2003. Tentang Sistem Pendidikan Nasional. Jakarta : Presiden Republik Indonesia

Widyastuti, Ratna Tri. 2015. "Pengembangan Jobsheet Praktikum Sistem Pengapian Untuk Meningkatkan Hasil Belajar Siswa Kelas XI" (Skripsi Jurusan Teknik Mesin, Fakultas Teknik, UNNES) 